\title{
The Application of Input Hypothesis to the Teaching of Listening and Speaking of College English
}

\author{
Wenquan $\mathrm{Wu}$ \\ Foreign Languages College, Qingdao University of Science and Technology \\ Qingdao 266061, China \\ E-mail: wuwenquan@qust.edu.cn
}

\begin{abstract}
Krashen's Input Hypothesis develops from his earlier theory-the Monitor Model, which is one of the major Second Language Acquisition Theories. Based on this Hypothesis, an emphasized comprehensible input means significance to the effect of teaching of listening and speaking of college English as well as to the improvement of the communicative skill of the college students.
\end{abstract}

Keywords: Input hypothesis, Comprehensible input, Teaching of listening and speaking

\section{Introductions}

Krashen's Input Hypothesis has enjoyed considerable prominence in Second Language Acquisition research. It has brought together research findings from a number of different domains, is closely tied to recommendations for classroom practice and is readily understandable to Second Language teachers. Drawing on this theory, the author tries to apply it to the teaching of listening and speaking of college English so as to make improvement in the English teaching.

\section{Input Hypothesis}

Krashen's Input Hypothesis is a comparatively comprehensive theory in the field of Second Language Acquisition research, which derives from its earlier version, the Monitor Model. The Monitor Theory consists of five hypothesizes, namely, the Acquisition-Learning Hypothesis, the Monitor Hypothesis, the Natural Order Hypothesis, the Input Hypothesis and the Affective Filter Hypothesis. As far as this research is concerned, the Natural Order Hypothesis and the Input Hypothesis are much more significant than the other three.

Krashen argues that language learners can develop their second language knowledge in two different ways: acquisition and learning. The term "acquisition" is used to refer to picking up a second language through exposure, whereas "learning" is used to refer to the conscious study of a second language (Ellis, 1985). In other words, acquisition occurs subconsciously as a result of participating in natural communication where the focus is on meaning; learning occurs as a result of conscious study of the formal properties of a language.

Krashen claims that a given learner acquires the rules of language in a considerably the same way and a predictable order (Cook 2000). This order is universal in nature. The learners acquire some rules earlier than others. In addition, there are on essential differences between inside and outside classroom learners in acquiring a second language. Krashen terms the order "Natural order", formulized as $R_{1} \ldots t R_{\mathrm{i}} \ldots R_{\mathrm{i}+1} \ldots R_{\mathrm{n}} . R_{1}$ refers to the first item of the language rules, $R_{\mathrm{n}}$ is assumed to be the last rule, $R_{\mathrm{i}}$ is the newly acquired rule or the current language competence of the learner, $t$ indicates the stage where the learner is, and $R_{\mathrm{i}+1}$ refers to the rule the learner will acquire next.

The Input Hypothesis attempts to explain how a learner acquires a second language. A number of researchers see "comprehensible input" as a major causative factor in second language acquisition. The most influential theoretical positions are those advanced by Krashen and Long (Ellis, 1985). Kranshen's Input Hypothesis makes the following claims: Learners progress along the natural order by understanding input that contains structures a little bit beyond their current level of competence. Three points are indicated in the above statement. Firstly, Natural Order Hypothesis is the theoretical basis of Input Hypothesis. Learners develop their language knowledge along the natural order. Secondly, in a sense, the most fundamental approach for a leaner to acquire a language is to understand the language input. Only when the language input is absorbed or internalized by the learner, acquisition can take place. Thirdly, Krashen and Long point out that comprehensible input refers to those language materials "a little bit beyond" the learner's current level, as Cook (Ellis, 1985) points out, "the input 
must be neither too difficult to understand nor too easy". If it only covers what the learner has learnt, the material is of no significance for language acquisition. Similarly, if the input is too advanced (highly beyond the learner's current level) for the learner to understand, acquisition will not take place either. For example, if there are more than one hundred new words in a thousand-word passage, the learner can not understand it at all. Let alone he can benefit from it.

"Comprehensible input" is formulized by Krashen as " $\mathrm{i}+1$ ". " $\mathrm{i}$ " refers to learner's current level of a second language. " $i+1$ " indicates the next stage in the learner's language development along the natural order. " 1 " refers to the gap between the current level and the next stage. Only characterized by " $\mathrm{i}+1$ ", the oral or written input can play a facilitating part in the learner's language development.

\section{Current Situations of the Teaching of Listening and Speaking of College English}

Gaining years of experience from the teaching of listening and speaking of college English, the author has observed some problems as follows.

\subsection{Unsatisfying teaching materials}

Now we can observe that the teaching materials have improved but still not so satisfying. There is still room of improvement in the teaching materials, the input. First of all, the arrangement of the teaching materials is not so logical and reasonable. Some long conversations or passages are presented at the beginning, which frustrates the learners in the first place. Secondly, there is too much information for listening and therefore the learners are much more immersed in listening and focus less on the speaking. So there is merely massive input and little output. Also, some of the teaching materials are rather dull and impractical. Thus, it will hinder the learners to go on to get more interested and involved in it.

\section{2 ineffective learners}

Due to the shortcomings of the teaching materials mentioned above, learners are sure to meet some obstacles of understanding in the process of listening. Thus, the teaching materials are not as comprehensible as expected. The result is an interfered comprehension which tends to turn a learner into a passive receiver. Like it or not, learner's enthusiasm toward learning is greatly affected. In this way, a learner is more likely to just take in the limited comprehensible input passively, which is surely not the effective way of language learning.

And also, the less input a learner gets, the less output he will produce. The ineffectiveness of the comprehensive input will undoubtedly lead to the decline of output, i.e. the speaking of English. If a learner could not have a full understanding of the teaching materials, he will occupy himself with the tangle of meaning, let alone pay attention to the output of the language.

\section{Solutions}

According to College English Curriculum Requirements, the objective of College English is to develop students' ability to use English in a well-rounded way, especially in listening and speaking. Under this direction, the Teaching of Listening and Speaking of College English should accordingly make some adjustment to make up the shortcomings mentioned above.

\subsection{Improvements of the teaching materials}

Teaching materials play an important role in the teaching of listening and speaking. All the teaching activities are centered on it. The quality and quantity of the teaching materials are the crucial factors for language learning.

\subsubsection{Comprehensibility of the teaching materials}

According to the Input Hypothesis, "comprehensible input" is a major causative factor in second language acquisition. And the most fundamental approach for a leaner to acquire a language is to understand the language input. So the comprehensibility of the teaching materials is the key. Here we can see, a suitable set of teaching materials for the learners is in bad need. For example, if the material is too easy for the learners to understand, they will gain nothing. On the contrary, if it is too difficult for the learners to understand, they will never get a clue neither. Thus an ideal set of teaching materials must content suitable comprehensibility.

\subsubsection{Significance of the teaching materials}

In order to facilitate a learner to acquire a second language, the significance of the teaching materials is also of vital importance. That is, the topics of the teaching materials should be interesting and relevant to learners. It is observed that when the topic of the teaching materials interests the learner, he/ she is more motivated and get more involved in the listening activity. Accordingly, the learners are much more likely to be much more successful. 


\subsubsection{Arrangement of the teaching materials}

As mentioned above, learners develop their language knowledge along the natural order. So it would be unadvisable if the whole teaching materials are of the same difficulty from the beginning to the end. It is natural order of the teaching materials that we should emphasis here, i. e. step by step. The arrangement of the teaching materials should be carefully designed, studied, tested and modified in a more scientific way so as to enhance the effectiveness of the learning.

\subsubsection{Continuity of the teaching materials}

According to the formula proposed by Krashen as " $i+1$ ", the learner's language development along the natural order. And there is the gap between the current level and the next stage. So once the current level is reached, there should be continuous input to keep the learner go on to the next stage. Otherwise, the learner will stop where he is. In a sense, the continuity of the teaching materials is a guarantee for the learner to take a further step in the learning.

\subsection{Improvements in the teaching process}

Asides from the teaching materials mentioned above, the conducting of teaching could also be improved to meet the need of the teaching of listening and speaking, which should never be neglected.

\subsubsection{Warm-up activities}

The purpose of the warm-up activities is to help students build a general idea about the teaching material by giving them a brief introduction, some key words and background information and enlightening them on the content of the teaching materials. First of all, the introduction of cultural background and related information is necessary. For example, when talking about sports in America, it is necessary for the teacher to introduce cultural background and related information such as football and baseball as well as the Super Bowl and the Major League Baseball. Such information will play a facilitating role in the understanding of the listening material. And also, prediction is another necessary way in the warm-up activities. One of the shortcomings mentioned above is that learners tend to be a passive listener, who has little time and focus less on the active thinking of the "comprehensible input". Prediction of the teaching materials is a way to solve this problem. By predicting, learners can transfer the passive listening to active thinking. And thus enhance their interest and capability of the listening materials.

\subsubsection{Response to the feedback}

One important way to make the classroom an excellent place for second language acquisition is to make timely responses to the feedback of the learners. Teachers should be fully aware of the competency of their students and make adjustment to their feedback accordingly. After all, "comprehensible input" is fundamental to the teaching of listening and speaking. Teachers are required to make more timely responses to the feedback to ensure than the learners get a full understanding of the teaching materials. And further teaching of listening and speaking would not be possible unless the teaching materials are better understood.

\subsubsection{Oral-presentation and group discussion}

College English Curriculum Requirements makes an urgent claim on developing students' ability to use English in a well-rounded way, so it is vital to develop the skill of speaking in our English classroom, especially in the teaching of listening and speaking. As we have pointed out earlier, the most fundamental approach for a leaner to acquire a language is to understand the language input. But that is only part of the story. In language learning, input and output are of the same significance. A good command of a language requires both the listening and speaking skill. So it is our responsibility to carry out the task of conducing more speaking task on the basis of the comprehensible input. An effective way to do it is to organize oral-presentation and group discussion of the related topic just listened. It helps to get a better understanding of the listening materials and practice the language points newly acquired. And it is the right way to realize the communicative function of language.

\subsubsection{Formative assessment}

It has been proved that formative assessment contributes to encouragement of motivation and promotion of autonomy. Motivation may link to different types of autonomy (Ecclestone, 2002: 33), but the relationship between autonomy and motivation in language learning has been a very controversial issue, the controversy being on whether it's autonomy that enhances motivation or it's motivation that produces autonomy. By making a survey of the relevant literature and meanwhile carrying out a large-scale study of Hong Kong tertiary students, Mary Spratt and her associates argue that "motivation may lead to autonomy or be a precondition for it" (Spratt, Humphreys and Chan, 2002), which is significant for the task of language learners' training, as it indicates where 
teachers should choose to place their teaching priorities. In situations where learners resist autonomous practices or reject or avoid learning opportunities, teachers may encourage autonomy by developing students' motivation to learn. Some language researchers argue that language teachers should pay great heed to the encouragement of the students' motivation to learn and the promotion of their learner autonomy (Hao Mei \& Hao Ruoping, 2001; He Lianzhen, 2003; Wu Heping, 2001). In a word, in the process of teaching of listening and speaking, teachers should make formative assessment to encourage learners' motivation and promote their autonomy.

\subsection{Appropriate error analysis}

Since errors constitute an important part of the learners' language, error analysis has become a useful technique of investigating and describing learners' language. The practical aspect of error analysis lies in its function in guiding the remedial activities to correct an unsatisfactory state of affairs for the learner or the teacher. In the classroom, an active second language learner will not need a great deal of overt correction of errors if the constructive and meaningful feedback of communicative contexts is present. However, some correction is beneficial. The teacher has to determine what errors to correct and how to correct them. According to Brown (1980:185), what to correct is dependent upon three criteria.

Firstly, the gravity of the error in reference to the effectiveness of communication: This is determined by how much an error interferes with communication. Minor errors that do not affect communication need not be corrected.

Secondly, the degree of linguistic deviance: Although comprehensible, a grossly ungrammatical sentence should be corrected for the sake of shaping linguistic forms.

Thirdly, the particular objective of the lesson: Errors in the structure or rule that is being taught should be corrected whereas other minor errors may be ignored.

In short, appropriate error analysis should be conducted in the listening and speaking classroom following these rules. It will yield insights into the language learning process which will eventually have direct relevance to the improvement of language teaching materials and methods.

\section{Conclusions}

It is time we take actions to improve the teaching of listening and speaking since the objective of College English is to develop students' ability to use English in a well-rounded way, especially in listening and speaking. By applying Input Hypothesis to the teaching of listening and speaking of College English, learners are likely to benefit more.

First of all, the "comprehensible input" can arouse their interest in the listening materials and thus intensify their desire to listen. So they can gain a better understanding of. Not only will the learners acquire some language, but also cultural background and related information beyond language they will acquire.

In the second place, the more learners listen and understand, the more they will imitate and speak. Consequently, the effectiveness of the input will facilitate more successful output. And as is well known, the basic function of language is to communicate. So learners can master a language by communicating in it. Moreover, apart from the language, there are also communicative skills learners will gain by practicing. In this sense, the teaching of listening and speaking is not merely a language class. It integrates language with culture and communicative skills.

Furthermore, the application of "comprehensible input" helps to build up learners' confidence and improve their critical thinking. Learners will reduce their anxiety greatly while getting "comprehensible input". And with appropriate error analysis, some of the errors can be tolerated. It helps to boost their confidence too. So learners are getting more chances involved in critical thinking, which proves to be a crucial factor in developing their ability to use English in a well-rounded way.

All in all, the Input Hypothesis inspires and benefits both the language learners and the teachers. It is of great value in improving second language acquisition as well as language teaching.

\section{References}

Brown, H. D. (1980). Principles of Language Learning and Teaching. Englewood Cliffs, New Jersey: Prentice-Hall, Inc.

Cook, V. (2000). Linguistics and Second Language Acquisition. Beijing: Foreign Language Teaching and Research Press.

Ecclestone, Kanthryn. (2002). Learning Autonomy in Post-16 Education: The politics and practice of formative 
assessment. Forence, KY, USA: Routledge.

Ellis, R. (1985). Understanding Second Language Acquisition. Oxford: Oxford University Press.

Hao, Mei \& Hao, Ruoping. (2001). Research on the Relationship between English Achievement and Achievement Motivation as well as Anxiety State: A Case Study. Foreign Language Teaching and Research, 33/2: 111-115.

He, Lianzhen. (2003). Learner Autonomy and its Development. Foreign Language Teaching and Research, 35/4: 287-289.

Krashen, S. D. (1982). Principles and Practice in Second Language Acquisition. Oxford: Pergamum Press.

Spratt, Mary, Humphreys, Gillian and Chan Victoria. (2002). Autonomy and Motivation: which comes first. Language Teaching Research 6/3: 245-266.

Wu, Heping. (2001). A Review of Research on L2/FL Learners' Motivation in the 1990s'. Foreign Language Teaching and Research, 33/2: 116-121. 